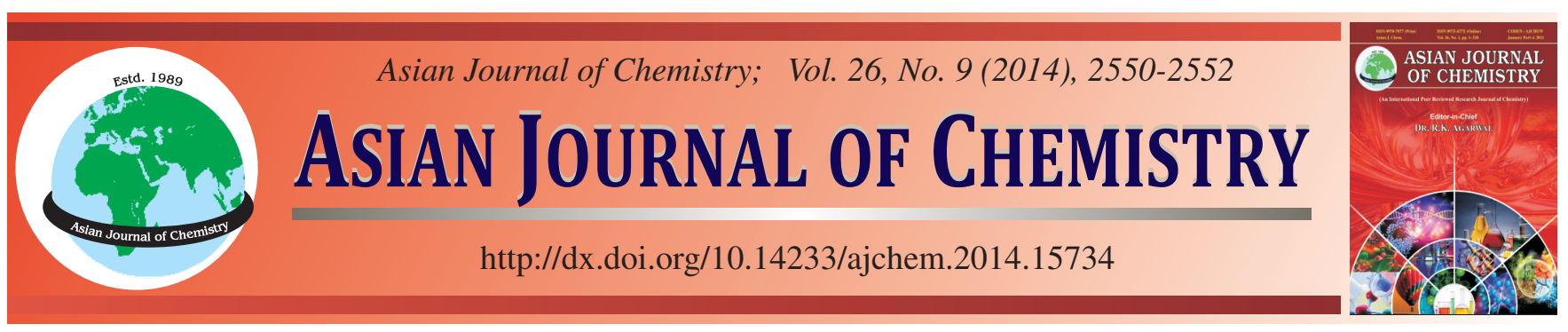

\title{
Synthesis, Structure and Antibacterial Properties of Bis-Imidazole-bis(naphthalene-1-yl-acetato)copper(II)
}

\author{
Gui ZhaO ${ }^{1}$, Fu-JUn YiN ${ }^{2, *}$, Hong-Yu GE ${ }^{1}$ and Shu-An $\mathrm{LI}^{2}$
}

${ }^{1}$ Huaihai Institute of Technology, Lianyungang 222005, P.R. China

${ }^{2}$ Jiangsu Marine Resources Development Research Institute, Huaihai Institute of Technology, Lianyungang 222005, P.R. China

*Corresponding author: E-mail: yinfujun2008@126.com

Received: 6 May 2013;

Accepted: 10 June 2013;

Published online: 28 April 2014;

AJC-15066

A copper(II) coordination, $\left[\mathrm{Cu}\left(\mathrm{C}_{12} \mathrm{H}_{9} \mathrm{O}_{2}\right)_{2}\left(\mathrm{C}_{3} \mathrm{H}_{4} \mathrm{~N}_{2}\right)_{2}\right]$ was synthesized and structurally characterized by means of X-ray single-crystal diffraction. It crystallizes in monoclinic space group P21/a, a = 17.849(4) $\AA, b=10.153(3) \AA, c=16.679(4) \AA ; \beta=111.351(3)^{\circ}$. Cu(II) cation is five-coordinated by 1-naphthylacetate anions and imidazole ligands to complete the distorted square-pyramidal coordination geometry. $\mathrm{Z}=4$. The antibacterial properties of the present $\mathrm{Cu}$ (II) complex were investigated as well. CCDC 835389 .

Keywords: $\alpha$-Naphthylacetic acid, Copper(II), Imidazole, Antibacterial.

\section{INTRODUCTION}

Recently there are much interest in the construction of coordination compounds due to their versatile structures and interesting topologies as well as their potential applications as functional materials in the fields of molecular magnetism, gas absorption and optoelectronic devices ${ }^{1-5}$. It is well-known that appropriate metal and various organic ligands are the two keys for design and construction of novel coordination complexes. The use of aromatic carboxylate ligands has attracted much attention due to its strong coordination ability and various coordination modes. The $\alpha$-naphthyl acetic acid (HNAA) is a very useful aromatic carboxylate ligand. It is a plant-growth regulator and our attention is focused on its coordination with the transition metal ions. Imidazole is a typically heterocyclic ligand with nitrogen as the donor atom. It exhibits a wide variety of pharmacological activities as antihelmintic, anticancer, antifungal and antiinflammatory agent ${ }^{6,7}$. It is a good candidate as a ligand to construct new coordination compound.

We have reported several complexes containing $\alpha$-naphthyl acetic acid previously ${ }^{8-12}$. Here, we report the synthesis and crystal structure of the title complex as part of an ongoing study of the properties of copper complex containing imidazole and $\alpha$-naphthyl acetic acid ligands.

\section{EXPERIMENTAL}

All reagents commercially available were of reagent grade and used without further purification. $\mathrm{C}, \mathrm{H}$ and $\mathrm{N}$ elements analyses were carried out on a Perkin-Elmer 240C elemental analyzer. FT-IR spectra were recorded on a Vector 22 FT-IR spectrophotometer by using $\mathrm{KBr}$ pellet in the range of 4000 $400 \mathrm{~cm}^{-1}$.

Synthesis of complex $\left[\mathrm{Cu}\left(\mathrm{C}_{12} \mathrm{H}_{9} \mathrm{O}_{2}\right)_{2}\left(\mathrm{C}_{3} \mathbf{H}_{4} \mathbf{N}_{2}\right)_{2}\right]$ : The title compound was synthesized by the reaction of $\mathrm{Cu}\left(\mathrm{CH}_{3} \mathrm{COO}\right)_{2} \cdot \mathrm{H}_{2} \mathrm{O}$ ( $99.8 \mathrm{mg}, 0.5 \mathrm{mmol}$ ), imidazole ( $34 \mathrm{mg}, 0.05 \mathrm{mmol}$ ) were added to $10 \mathrm{~mL} \mathrm{H}_{2} \mathrm{O}$ and after being stirred at room temperature for $0.5 \mathrm{~h}$, a $10 \mathrm{~mL} \alpha$-naphthyl acetic acid (186 mg $1 \mathrm{mmol})$ methyl alcohol solution was added to the solution. The mixture was homogenized and transferred into a sealed Teflon-lined solvothermal bomb (volume: $25 \mathrm{~mL}$ ) and heated to $423 \mathrm{~K}$ for three days. After cooling to room temperature, title compound was obtained, which were washed with distilled water and absolute ethanol [yield: $48.5 \%$ based on $\mathrm{Cu}\left(\mathrm{CH}_{3} \mathrm{COO}\right)_{2} \cdot \mathrm{H}_{2} \mathrm{O}$ ]. Anal. calcd. (\%) for $\left[\mathrm{Cu}\left(\mathrm{C}_{12} \mathrm{H}_{9} \mathrm{O}_{2}\right)_{2}\left(\mathrm{C}_{3} \mathrm{H}_{4} \mathrm{~N}_{2}\right)_{2}\right]: \mathrm{C}, 63.15 ; \mathrm{H}, 4.56 ; \mathrm{N}$, 9.82; Found (\%): C, 63.05; H, 4.45; N, 9.79. IR (KBr, $v_{\max }$, $\left.\mathrm{cm}^{-1}\right): 3431,3144,3060,2931,2869,1510,1328,1292,1259$, 1150, 1072, 1018, 954, 779, 752, 710, 656, 619, 582,542.

Biological activity: The in vitro antibacterial activity of the ligand and title complex on Escherichia coli, Bacillus subtilis and Golde stap were determined by disc diffusion method using nutrient agar ${ }^{13}$. Biotechnology Laboratory of Huaihai Institute of Techology Marine Institute provides bacteria. Each of the compound was dissolved in DMF and solutions with the concentration of 25,50 and $100 \mathrm{mg} / \mathrm{L}$ were prepared separately. With a pipette $100 \mu \mathrm{L}$ DMF preparation of different concentrations of the test solution was added to the Oxford cup and then the all Oxford cups were placed in $37^{\circ} \mathrm{C}$ incubator for $24 \mathrm{~h}$, measure the inhibition zone diameter 
$(\mathrm{mm})$ size of each specimen, parallel test three times, an average value as the final experimental result.

X-Ray structure determinations: The crystal data collection for title complex was carried out on a Bruker Smart Apex II CCD at room temperature, using graphite-monochromated $\operatorname{MoK}_{\alpha}$ radiation $(\lambda=0.0 .71073 \AA)$. The structure was solved by direct methods and refined on $\mathrm{F}^{2}$ by full-matrix least-squares techniques with SHELXL-97 ${ }^{14}$. All non-hydrogen atoms and hydrogen atoms were refined anisotropically and isotropically, respectively. The hydrogen atoms were generated geometrically. Details of the crystal parameters, data collection and refinement for complexes 1 are summarized in Table-1. Selected bond lengths and angles with their estimated standard deviations for complex are listed in Table-2 and hydrogen-bonding parameters in Table-3. Crystallographic data for the structure of title complex in this paper have been deposited with the Cambridge crystallographic Data Center as supplementary publication No. CCDC 835389.

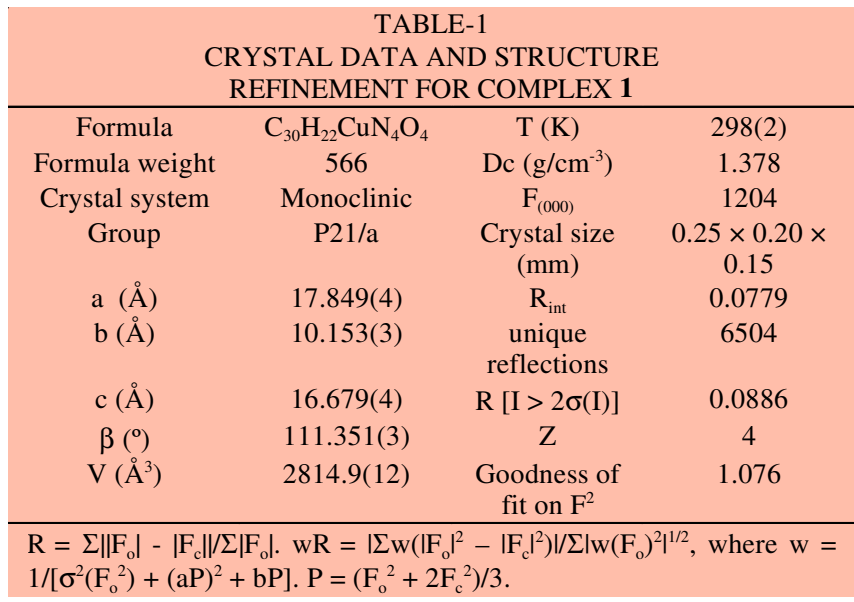

\begin{tabular}{cccc}
\multicolumn{5}{c}{ TABLE-2 } \\
SELECTED BOND LENGTHS $(\AA)$ \\
\multicolumn{4}{c}{ AND ANGLES $\left(^{\circ}\right)$ FOR COMPLEX } \\
\hline $\mathrm{Cu}(1)-\mathrm{N}(1)$ & $1.963(6)$ & $\mathrm{N}(3)-\mathrm{Cu}(1)-\mathrm{O}(3)$ & $92.3(2)$ \\
$\mathrm{Cu}(1)-\mathrm{N}(3)$ & $1.981(5)$ & $\mathrm{O}(2)-\mathrm{Cu}(1)-\mathrm{O}(3)$ & $174.33(18)$ \\
$\mathrm{Cu}(1)-\mathrm{O}(2)$ & $1.987(4)$ & $\mathrm{C}(1)-\mathrm{O}(2)-\mathrm{Cu}(1)$ & $120.4(5)$ \\
$\mathrm{Cu}(1)-\mathrm{O}(3)$ & $2.004(4)$ & $\mathrm{C}(13)-\mathrm{O}(3)-\mathrm{Cu}(1)$ & $119.8(4)$ \\
$\mathrm{N}(1)-\mathrm{Cu}(1)-\mathrm{N}(3)$ & $171.4(2)$ & $\mathrm{C}(28)-\mathrm{N}(3)-\mathrm{C}(30)$ & $105.3(7)$ \\
$\mathrm{N}(1)-\mathrm{Cu}(1)-\mathrm{O}(2)$ & $89.2(2)$ & $\mathrm{C}(28)-\mathrm{N}(3)-\mathrm{Cu}(1)$ & $129.3(5)$ \\
$\mathrm{N}(3)-\mathrm{Cu}(1)-\mathrm{O}(2)$ & $88.7(2)$ & $\mathrm{C}(30)-\mathrm{N}(3)-\mathrm{Cu}(1)$ & $125.3(5)$ \\
$\mathrm{N}(1)-\mathrm{Cu}(1)-\mathrm{O}(3)$ & $90.6(2)$ & - & - \\
\hline
\end{tabular}

\begin{tabular}{ccc} 
TABLE-3 \\
DISTANCE $(\AA)$ AND ANGLES $\left({ }^{\circ}\right)$ OF \\
HYDROGEN BONDS FOR THE COMPLEX 1 \\
\hline D-H $\cdots$ A & Distance $(\mathrm{D} \cdots \mathrm{A})$ & Angle $(\mathrm{D}-\mathrm{H}-\mathrm{A})$ \\
\hline N4-H4...O1_\#1 & $2.818(9)$ & 159.6 \\
N2-H2...O4_\#2 & $2.801(8)$ & 170.6 \\
\hline Symmetry codes: \#1 $-\mathrm{x}+1,-\mathrm{y}+1,-\mathrm{z} ;$; $\# 2:-\mathrm{x}+1, \mathrm{y}+1 / 2,-\mathrm{z}+1 / 2$. \\
\hline
\end{tabular}

Structure description of $\mathrm{Cu}(\mathrm{II})$ complex: The crystallographic analysis reveals that the title complex is a dinuclear molecule coordination compound (Fig. 1), which illustrates the coordination diagram with atomic numbering scheme.

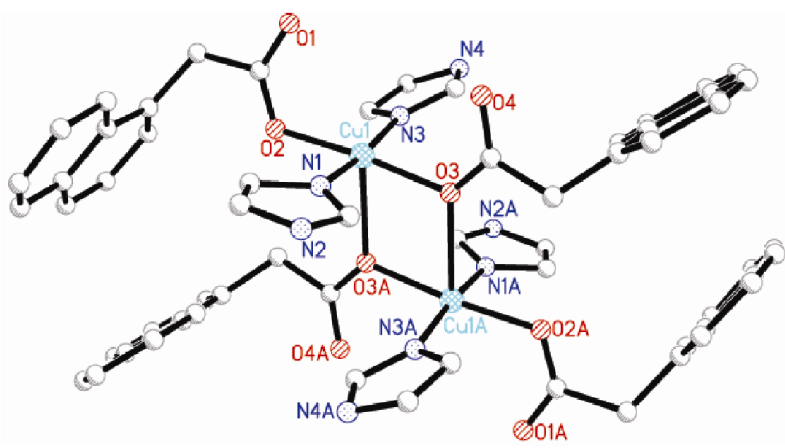

Fig. 1. Coordination environment of $\mathrm{Cu}(\mathrm{II})$ atom in $\mathbf{1}$, the hydrogen atoms omitted for clarity. O1A, O2A, O3A, O4A, N1A, N2A,N3A,N4A: $1-\mathrm{x}, 2-\mathrm{y},-\mathrm{z}$

The title copper(II) complex structure is shown in Fig. 1. The asymmetric unit consists of two $\alpha$-naphthyl acetic acid molecule and two imidazole molecule. Each copper cation are coordinated by two $\mathrm{N}$ atoms of two symmetry equivalent imidazole ligands and by two carboxyl $\mathrm{O}$ atoms of two symmetry related $\alpha$-naphthyl acetate anions (Fig. 1), O2, O3, $\mathrm{N} 2, \mathrm{~N} 3$ are in the basal plane. O3A (symmetry code: 1-x,2-y,-z) coordinates to the $\mathrm{Cu}$ (II) cation in the apical position to complete the distorted square-pyramidal coordination geometry. The $\mathrm{Cu}$ (II) cation is 0.0105 (9) $\AA$ deviated from the basal coordination plane in the direction of the apical O3A atom, which is consistent with the situation found in complexes with squarepyramidal coordination geometry ${ }^{9}$. The $\mathrm{Cu}-\mathrm{O} 3 \mathrm{~A}$ bond in the apical direction is 2.4789(61). The $\mathrm{Cu}-\mathrm{N}$ and $\mathrm{Cu}-\mathrm{O}$ bond lengths are 1.963(6), 1.981(5) and 1.987(4), 2.004(4) $\AA$ in the basal plane. The apical $\mathrm{Cu}-\mathrm{O} 3 \mathrm{~A}$ bond is longer than other $\mathrm{Cu}-\mathrm{O}$ bonds in the basal plane by $0.5 \AA$, showing the typical Jahn-Teller distortion. Each $\alpha$-naphthyl acetic acid anion bridges two $\mathrm{Cu}(\mathrm{II})$ cations to form the centro-symmetric dinuclear complex. Within the dinuclear molecule the $\mathrm{Cu} \cdots \mathrm{Cu}$ separation is 3.5415 (13) $\AA$, longer than $\mathrm{Cu}$... Cu separation in the reported $\mathrm{Cu}(\mathrm{II})$ complex ${ }^{15,16}$. The $\mathrm{O}-\mathrm{Cu}-\mathrm{N}$ angle are from $88.7(2)^{\circ}$ to $92.3^{\circ}$. The angles of $\mathrm{O}(2)-\mathrm{Cu}(1)-\mathrm{O}(3)$ and $\mathrm{N}(1)-\mathrm{Cu}(1)-\mathrm{N}(3)$ are 171.4(2), 174.33(18), respectively. The dihedral angle formed by adjacent $\alpha$-naphthyl acetic acid ring is $20.04^{\circ}$ the distance between the centre of adjacent $\alpha$-naphthyl acetic acid ring is $4.2017(8)$ which suggests no $\pi-\pi$ stacking between $\alpha$-naphthyl acetic acid ring systems.

Adjoining molecules are linked into one-dimensional crystal structure by N-H …O hydrogen bonds (Table-3, Fig. 2), further, one-dimensional network of title complex is linked together by hydrogen bonds to generate two-dimensional structure (Fig. 3).

Antibacterial activity: According to the "Technical Standard for Disinfection" ${ }^{\prime 3}$ : the antibacterial circle diameter greater than $20 \mathrm{~mm}$ has a strong inhibitory effect, bacteriostatic circle in $10-20 \mathrm{~mm}$ for moderate antibacterial, bacteriostatic circle is less than $10 \mathrm{~mm}$ for weak inhibitory, inhibitory effect is shown in Table-4, experiments show that, the ligand and the complex have antimicrobial effect of moderate to three kinds of tested bacteria, solvent DMF on almost no inhibition of bacteria. Due to the increase of the ligand concentration, the inhibition zone diameter also increased, antibacterial activity and also enhanced. There is no linear relationship between the concentration of complex and the antimicrobial effect. 


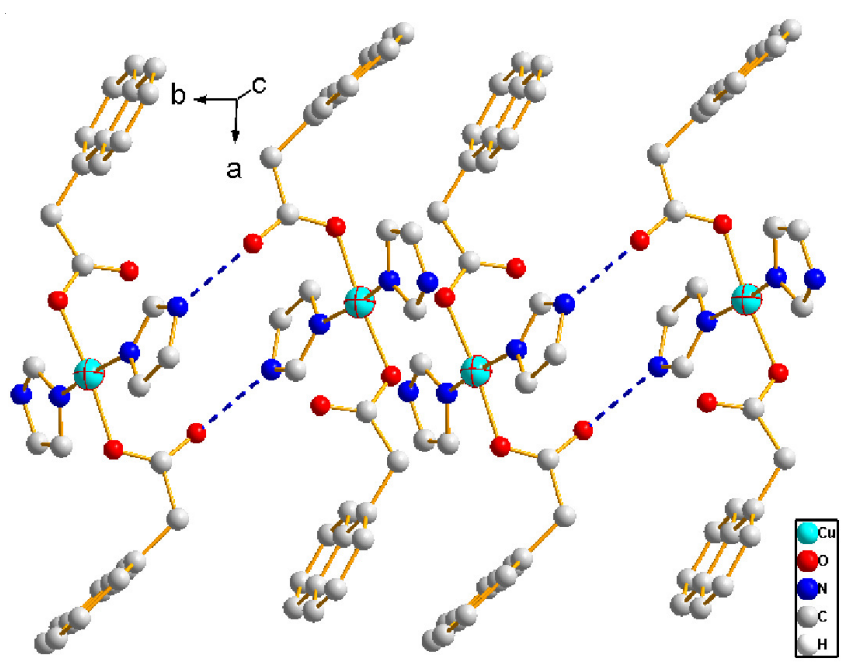

Fig. 2. Part of the chain structure of the title compound. Hydrogen bonds are shown as dashed lines. $\mathrm{H}$ atoms not involved in hydrogen bonds are omitted for clarity

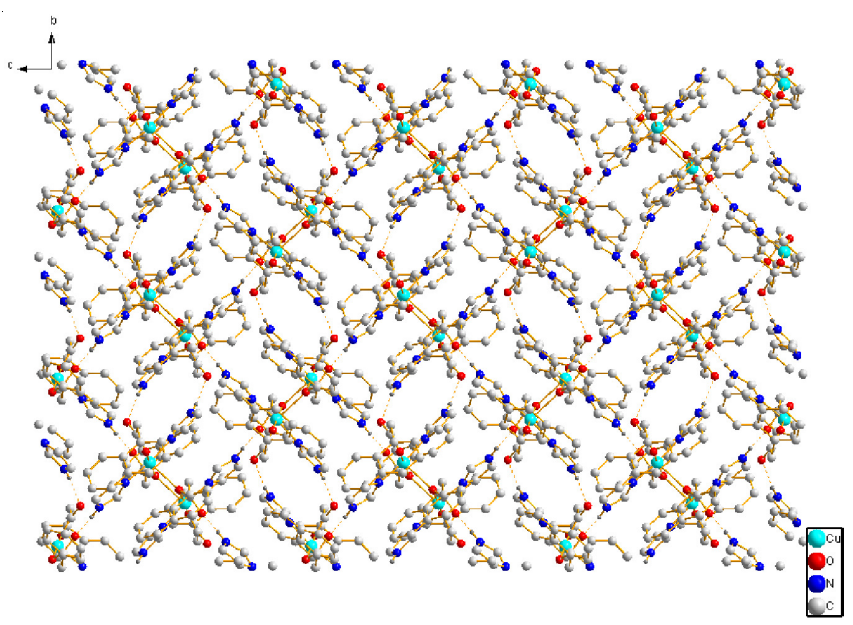

Fig. 3. Crystal packing diagram for title complex

\begin{tabular}{|c|c|c|c|c|}
\hline \multicolumn{5}{|c|}{$\begin{array}{c}\text { TABLE-4 } \\
\text { DIAMETER OF ANTIBACTERIAL HALO OF } \\
\text { THE TITLE COMPLEX AND THE LIGAND }\end{array}$} \\
\hline \multirow{2}{*}{ Comp. } & \multirow{2}{*}{$\begin{array}{l}\text { Concentration } \\
\left(\mathrm{mg} \mathrm{mL}^{-1}\right)\end{array}$} & \multicolumn{3}{|c|}{ Diameter (mm) of antibacterial activity } \\
\hline & & E. coli & B. subtilis & G. stap \\
\hline \multirow{5}{*}{1} & 1.00 & 15.0 & 16.0 & 14.5 \\
\hline & 0.50 & 14.5 & 12.0 & 12.5 \\
\hline & 0.10 & 10.5 & 13.0 & 11.5 \\
\hline & 0.05 & 15.0 & 12.0 & 14.0 \\
\hline & 0.01 & 13.0 & 12.0 & 11.5 \\
\hline \multirow{5}{*}{$\mathrm{L}$} & 1.00 & 15.0 & 9.5 & 11.5 \\
\hline & 0.50 & 14.5 & 15.0 & 12.0 \\
\hline & 0.10 & 15.0 & 14.0 & 11.5 \\
\hline & 0.05 & 15.5 & 15.0 & 11.5 \\
\hline & 0.01 & 16.0 & 14.5 & 11.0 \\
\hline DMF & - & 8.0 & 8.1 & 8.2 \\
\hline
\end{tabular}

\section{ACKNOWLEDGEMENTS}

A Project Funded by the Priority Academic Program Development of Jiangsu Higher Education Institutions.

\section{REFERENCES}

1. L. Carlucci, G. Ciani and D.M. Proserpio, Coord. Chem. Rev., 246, 247 (2003).

2. S. Kitagawa, R. Kitaura and S. Noro, Angew. Chem. Int. Ed., 43, 2334 (2004).

3. J.L.C. Rowsell, A.R. Millward, K.S. Park and O.M. Yaghi, J. Am. Chem. Soc., 126, 5666 (2004).

4. H.-Y. An, E.-B. Wang, D.-R. Xiao, Y.-G. Li, Z.-M. Su and L. Xu, Angew. Chem. Int. Ed., 45, 904 (2006).

5. G. Tian, G.S. Zhu, X.Y. Yang, Q.R. Fang, M. Xue, J.Y. Sun, Y. Wei and S.L. Qiu, Chem. Commun., 1396 (2005).

6. L.N. Parshina and B.A. Trofimov, Russ. Chem. Bull., 60, 601 (2011).

7. K. Shalini, P.K. Sharma and N. Kumar, Pelagia Res. Lib., 1, 36 (2010).

8. F.J. Yin, H. Zhao and X.L. Hu, Synth. React. Inorg., Met-Org. NanoMetal Chem.., 40, 606 (2010).

9. F.J. Yin, H. Zhao and X.L. Hu, Synth. React. Inorg., Met-Org. NanoMetal Chem., 40, 535 (2010).

10. F.-J. Yin, H. Zhao, X.-Y. Xu and X.-J. Yang, Chin. J. Inorg. Chem., 29, 589 (2013).

11. F.-J. Yin, H. Zhao, X.-Y. Xu and X.-J. Yang, Chin. J. Inorg. Chem., 28, 1700 (2012).

12. F.-J. Yin, Y. Gu, H. Zhao and D.-S. Bai, Acta Cryst., E68, m350 (2012).

13. G.-Z. Liu, Micro-Biology and the Detect of Micro-Biology, Beijing: People's Medical Publish House (1987).

14. G.M. Sheldrick, SHELX-97, Program for the Solution and Refinement of Crystal Structures, University of Göttingen, Germany (1997).

15. D.-X. Li, D.-J. Xu and Y.-Z. Xu, J. Coord. Chem., 60, 2687 (2007).

16. M.-J. Li, J.-J. Nie and D.-J. Xu, Acta Crystallogr., E65, m881 (2009). 